\title{
Applying the New Methodology for Determining the Suitability of Land for Fruit Production
}

\author{
Ştefan BAKOS ${ }^{1 *}$, Marilena MĂRGHITAȘ² \\ ${ }^{1}$ Office of Soil and Agrochemical Studies Cluj, Fagului 1, Cluj-Napoca, Romania \\ ${ }^{2}$ University of Agricultural Sciences and Veterinary Medicine Cluj-Napoca, Faculty of Agriculture, \\ Manastur 3-5, 400372, Cluj-Napoca, Romania \\ *Corresponding author: bakosstefan@yahoo.com \\ Bulletin USAMV series Agriculture 72(2)/2015 \\ Print ISSN 1843-5246; Electronic ISSN 1843-5386 \\ DOI 10.15835/buasvmcn-agr: 11728
}

\begin{abstract}
This paper makes reference to the specific conditions for applying the new methodology for estimating pedoclimatic resources in terms of land suitability for fruit production. The old system fit the fruit growing lands in 6 categories of suitability taking into account the following indicators: soil thickness, useful edaphic volume, degree of salting and alkalinity, depth of horizon $\mathrm{Cca}$, active $\mathrm{CaCO}_{3}, \mathrm{pH}$, mobile $\mathrm{Al}$, vertic character, slope, degree of unevenness, the degree of erosion, landslides, groundwater, global drainage, non-gleyed soil volume, intensity excess moisture and flooding danger. This simplified model of the new methodology was applied in two stages: in the first stage was included the individual assessment of the suitability of species depending on soil variables ( $\mathrm{pH}$, texture and drainage) and on climate (average temperatures, extreme daily rainfall and the absolute minimum temperature during the growing season. In the second phase were combined suitability scores of soil and climate, thus resulting in a quantitative estimates (with numeric values between 0 and 4): the range between 0 and 0.5 is considered unfavorable, the range between 0.5 and 1.5 is considered a little favorable, between 1.5 and 2.5 moderately favorable, between 2.5 and 3.5 favorable, and more than 3.5 notes will give very favorable ratings of that location. For a project to be eligible for funding the minimum grade is 2.4. If that location is considered at low favorability, below 2.4, then, on demand, potentiation may be applied depending on the evaluation notes and pedoclimatic factors of that zone.
\end{abstract}

Keywords: fruit-grower, methodology, pedo-climatic factors, suitability.

\section{INTRODUCTION}

Favorability maps for the orchards territory were created using computer programming techniques and programs specialized in geostatistical interpolation. They compare climate and pedo-logical conditions from orchards basins with requirements to soil and climate for each crop.

Determination of thermal favorability is based on sinusoidal functions used in simulation programs (Anderson and Richarson, 2006, Gaoudriaan van Laar, 1994), taking as input the average temperature, absolute minimum and maximum temperatures and precipitation annual average. With the equations that convert daily temperature in hourly values, was created subroutine that provides data about temperatures between thermal reference marks, thereby acquiring 366 values between 0 and 4 of suitability daily. In order to establish the annual favorability were calculated the average daily sum of notes during the growing season, then divided by the number of days during the growing season.

Similarly favorability was done to establish the vegetation period (DSV) and the degree of favorability to winter frosts, using the database of 
minimum temperature values for the last 50 years (INCDPAPM-ICPA, 2014)

Determination of pedological suitability cartograms was based on texture interpretation of soils and internally drainage reaction being similarly granted favorability scores between 0 and 4 (INCDPAPM-ICPA, 2014).

\section{MATERIALS AND METHODS}

The research was conducted in the town Seini, Maramures County, the land being occupied by an old orchard, currently without productive potential. The aim of the research is to determine the suitability of the land for cherry trees. In Annex STP within 4.1a measure of Seini city is framed in that the cherry tree potentially is reduced in this area: by 1.93 points of favorability and 2.75 points for natural potentiated favorability.

Description of specific climatic conditions of the area studied, delineation and definition of soil and ground units, and chemical soil analysis of the main attributes was made after "Soil Assessment Study Methodology (Florea et al.,1987), developed by ICPA Bucharest, 1987", as well as "Romanian system of Soil Taxonomy" (Florea et al.,2012)", "Agrochemical Treaty" (Rusu et al.,2005).

Determining of soil analyzes were made using the following methods: $\mathrm{pH}$ - potentiometric, humus - Walklez-Black, total nitrogen - Kieldahl, soil texture - Kacinsky, sum of bases - Kappen, hydrolytic acidity - extraction method, mobile aluminum - Sokolov, soil drainage depending on soil type and textural class.

\section{RESULTS AND DISCUSSIONS}

Seini town is situated in the western part of Maramures county, in the area of contact between the western limit of Somes Plain and western extensions of Gutai Mountains.

From a geological point of view the land consists of a base belonging to the Miocene, characterized by geological formations like Burdigalian and Helvețian represented by clays and marl sandstones near surface, noncarbonated clays in this case, having a major role in the formation of soil cover.

In terms of hydrography, researched area belongs to the Somes river basin, with water table located between 3 and $5 \mathrm{~m}$.

From a climate perspective studied area falls within Dfbx climatic region (Cernescu), and is characterized by hot summers, long autumns and mild winters with an average annual temperature of $9.41^{\circ} \mathrm{C}$ and precipitation that reach an annual average of $602 \mathrm{~mm}$. The land of hills is characterized by hot summers, not too rich in precipitations and cold winters with unstable snow cover.

Record total radiation values were between $120 \mathrm{kcal} / \mathrm{cm}^{2} /$ year in Somes Plain and less than 100 $\mathrm{kcal} / \mathrm{cm}^{2} /$ year on high peaks of mountains. The air

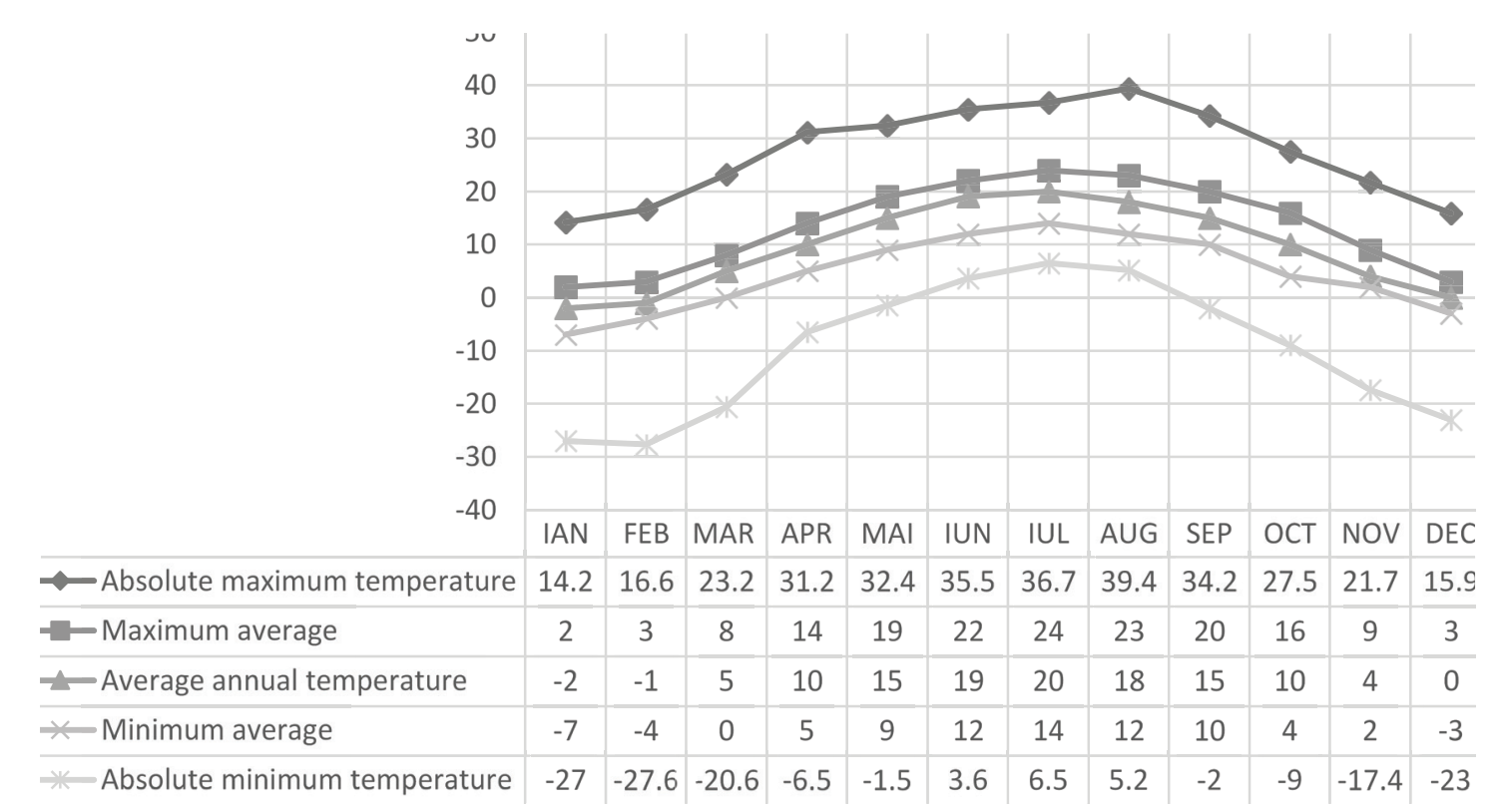

Fig. 1. The thermal regime $\left({ }^{\circ} \mathrm{C}\right)$ Seini 
temperature shows large regional differences due to differences in altitude and exposure to eastern winds and solar radiation. The annual average temperature of $9.41^{\circ} \mathrm{C}$ varies at Seini, warmest month averages - July are between $20-21^{\circ} \mathrm{C}$, while the coldest month - January decreased to approx. $-2^{\circ} \mathrm{C}$. Seini absolute maximum values reached in August 16, 1952, $39.4{ }^{\circ} \mathrm{C}$ and the absolute minimum in February 27, 1952, $-27.6{ }^{\circ} \mathrm{C}$.

Winds are strongly influenced by landscape both in terms of direction and speed. The wind is calm and annual average frequency has low levels (21.8\%).

The average annual temperature varies between $9.0-9,5^{\circ} \mathrm{C}$, with average monthly temperatures between $-2{ }^{\circ} \mathrm{C}$ in January and $20^{\circ} \mathrm{C}$ in July. Temperature variation is mild specific to continental climate type, with maximum in July (average temperature $20{ }^{\circ} \mathrm{C}$ ), while the minimum in January (average temperature $-2^{\circ} \mathrm{C}$ ). The transition from winter to spring is slow, usually in the second decade of April. Summers are pleasant, with hot temperatures. Autumn is characterized by moderate rainfall, warm rain and sometimes extends until November. Winter temperature inversions occur.

To be noted that if the plot is located on a plan land, is not operating according to the slope corrections and exhibition in the calculation of evaluation sheet.

The average number of days possible without freezing is approx. 250. Hoarfrost occurs early in the second decade of September and become frequent in October, and the latter ones that occur in March and April are common.

The average annual precipitation ranges from $550-600 \mathrm{~mm} /$ year and continental variation is minimum in late winter (February) and maximum in early summer (June).

The average duration of sunshine, is situated around 2000-2200 hours/year.

Soil type is typical luvosol, identified according SRTS 2012, belonging to the luvisols class, having the following pedological formula: Ao 0-18 cm/ El 18-42 cm/ E/B 42-64 cm/ Bt 64-125 cm. Soil chemical and physical analyzes are shown in Tab. 1.

According to the table above one could notice that the soil has a weak acidic reaction in the first horizons and the texture in the first $50 \mathrm{~cm}$ is clayey or sandy loamy, being elements that are interested in granting suitability notes for cherry tree. Given grade temperature, given that the absolute maximum temperature for the species is $40{ }^{\circ} \mathrm{C}$, the absolute minimum temperature of $6{ }^{\circ} \mathrm{C}$, is granted the maximum grade, i.e. 4 .

The algorithms for calculating the favorability of frost resistance: if resistance limit of the cherry tree $\left(-30^{\circ} \mathrm{C}\right)$ should be less than or equal to the absolute minimum recorded in the last 50 years $\left(-27.6{ }^{\circ} \mathrm{C}\right)$ is given a 0 score. Since the difference is $2.4{ }^{\circ} \mathrm{C}$, is applied the algorithm $\mathrm{P}>$ Limit +2 , so note 3 .

Establishing the degree of favorability on vegetation period, given that the cherry tree has the minimum of 180 days and the number of days without frost is 250 days, is given note 4 . In fact

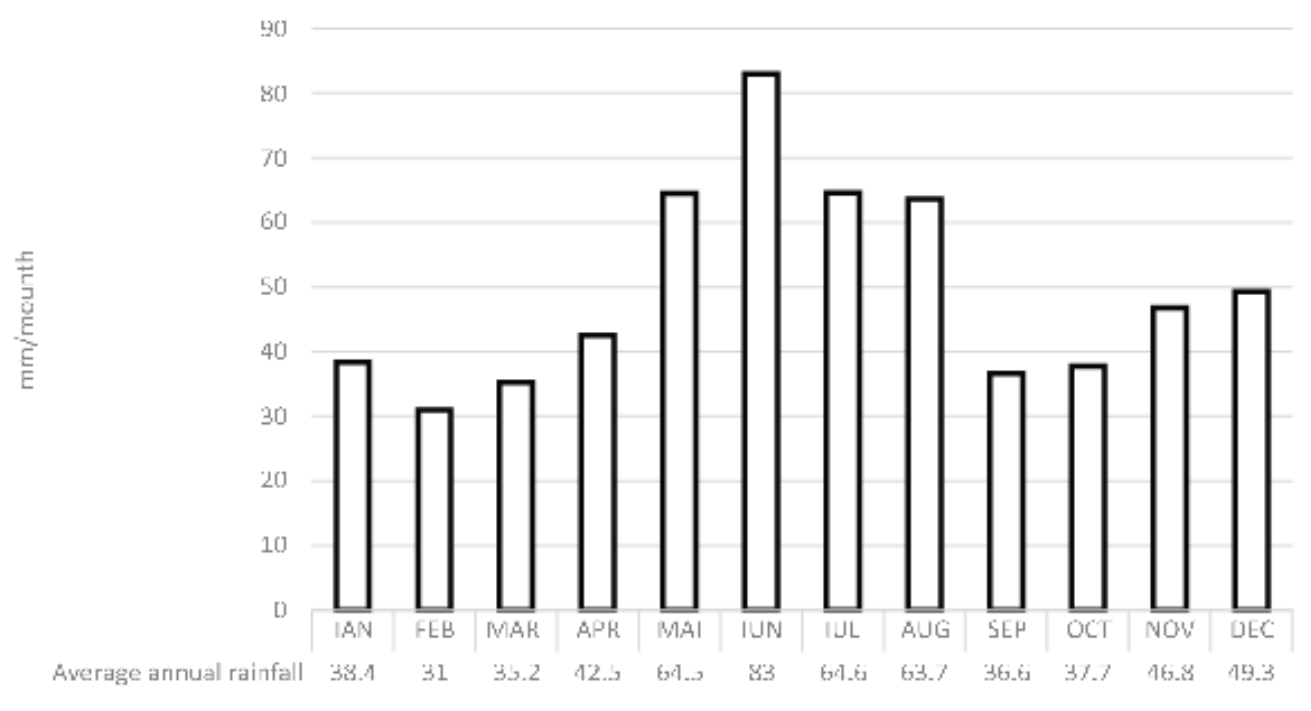

Fig. 2. The precipitation regime (mm/month) Seini 
for all settlements in Romania, except for the pear, apricot and strawberry trees, its corded note 4 , DSV not being considered a limiting factor.

To determine the suitability of precipitation, was used the mean on the interval 1961-2010. The minimum for the cherry tree species is 500 $\mathrm{mm}$ / year, maximum is $900 \mathrm{~mm}$ / year, therefore amplitude is $400 \mathrm{~mm}$ for the cherry tree. In this case we have the algorithm MIN + $0.75^{*}$ Amplitude $=800 \mathrm{~mm}$, equivalent to favorability note 3 .

For soil texture (sandy loam) in the methodology is given note 3 . The favorable conditions for soil $\mathrm{pH}$ is 3 , grade 4 is given in this case but for a neutral $\mathrm{pH}$. The degree of favorability for drainage is 3 , with a texture soil disturbance differentials profile being moderate at best. The formula to calculate the overall suitability is:

$\left(\frac{\text { Temp. note }+ \text { Drainage note }+ \text { Texture note }+p H \text { note }}{4}\right)$

$\left(\frac{\text { Frost note } * \text { Precipitation note } p * D S V \text { note }}{64}\right)^{0.3}$

Replacing the grades above have:

$\left(\frac{4+3+3+3}{4}\right) *\left(\frac{3 * 3 * 4}{64}\right)=2.73$

So by potentiating, the note rose to 1.93 (natural favorability given for this administrative area) at 2.73 , therefore is a favorable land for growing cherry trees (between 2.5 and 3).

If we apply the old methodology grouping criteria depending on land suitability of land for fruit growing we have:

Through this method follows that studied land has a middle suitability with moderate limitations, providing productions sized land in unimproved conditions. Differences from the first method that came from given penalties are higher, especially for heat and rainfall regime, and exchangeable aluminum content in soil.

\section{CONCLUSION}

Condition of various relief, parent rock, climate and soil physical and chemical attributes of the investigated area offers a good suitability for growing cherry tree. Even if in Annex STP 4.1a provides a measure within the suitability grade of 1.93 , by potentiating was obtained a note 2.73 , so a good suitability.

Restrictive factors that have penalized Cherry tree crop are: moderate soil drainage, texture profile differentials, $\mathrm{pH}$ - weak acid, resistance to frost and rainfall regime, but without imposing severe restrictions.

Old methodology, according to the Methodology elaborate soil studies, Vol. II, Annex 6-7, take into account several limiting factors, in particular physico-chemical attributes of the soil, thus framing the land suitability class is one unit lower compared to the new instructions.

By comparing the two methods, emerge some advantages and disadvantages of the new methods to determine the suitability of land for fruit growing:

The main advantage lies in modern processing climate and pedological data using computational algorithms, which were drawn favorability maps for fruit crops using for this software techniques and specialized in geo-statistical interpolation (ARCGIS-ESRI, Surfer 9.11.947, Golden Software INC.).

In addition it shows tables with concrete values for each fruit tree species in terms of their

Tab. 1 Physico-chemical analysis of the soil

\begin{tabular}{|c|c|c|c|c|c|c|c|c|c|c|c|}
\hline \multirow[b]{2}{*}{$\begin{array}{l}\text { Horizon / } \\
\text { Depth } \\
\mathrm{cm}\end{array}$} & \multirow[b]{2}{*}{$\mathrm{pH}$} & \multirow[b]{2}{*}{$\begin{array}{c}\text { Humus } \\
\%\end{array}$} & \multirow[b]{2}{*}{$\begin{array}{c}\text { SB } \\
\text { me } / 100 \\
\text { gr sol }\end{array}$} & \multirow[b]{2}{*}{$\begin{array}{c}\text { Ah } \\
\text { me/100 } \\
\text { gr sol }\end{array}$} & \multirow[b]{2}{*}{$\begin{array}{l}\mathrm{V} \\
\%\end{array}$} & \multirow[b]{2}{*}{$\begin{array}{c}\text { Al } \\
\text { me/100 } \\
\text { gr sol }\end{array}$} & \multicolumn{5}{|c|}{ Particle size analysis } \\
\hline & & & & & & & 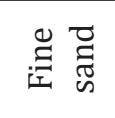 & 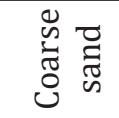 & $\begin{array}{l}\overrightarrow{\breve{n}} \\
\underline{\underline{n}}\end{array}$ & $\begin{array}{l}\bar{\Xi} \\
\overrightarrow{0} \\
\tilde{\theta}\end{array}$ & $\frac{\vec{\sigma}}{\mathrm{U}}$ \\
\hline $\begin{array}{c}\text { Ao } \\
0-18 \\
\end{array}$ & 6.12 & 2.18 & 8.6 & 3.03 & 74 & 0.23 & 18.1 & 36.85 & 5.6 & 15.3 & 24.15 \\
\hline $\begin{array}{c}\text { El } \\
18-42 \\
\end{array}$ & 6.18 & 1.42 & 7.88 & 2.75 & 74 & 0.32 & 61.22 & 17.28 & 3.4 & 4.0 & 14.1 \\
\hline $\begin{array}{c}\text { E/B } \\
42-64 \\
\end{array}$ & 6.42 & 0.64 & 9.32 & 3.23 & 74 & 0.11 & 16.74 & 31.33 & 5.95 & 14.8 & 31.45 \\
\hline $\begin{array}{c}\mathrm{Bt} \\
64-125\end{array}$ & 6.71 & 0.22 & 11.36 & 3.94 & 77 & 0.02 & 18.56 & 25.54 & 8.5 & 13.9 & 33.5 \\
\hline
\end{tabular}


Tab. 2 The criteria for grouping of land according to land suitability for growing cherry tree

\begin{tabular}{lcc}
\hline \multicolumn{1}{c}{ Indicator } & Code & $\begin{array}{c}\text { Suitability } \\
\text { Class }\end{array}$ \\
\hline The thickness of the soil to compact rock (ind.19) & 113 & I \\
\hline Useful edaphic volume (ind.133) & 113 & I \\
\hline Degree of salinization (ind.16) & 00 & I \\
\hline Degree of alkalinity (ind.17) & 00 & I \\
\hline Depth of horizon Cca (ind.18) & 250 & I \\
\hline Active CaCO3 (ind.62) & Absent & I \\
\hline The reaction of soil up to 100 cm (ind.63) & 6.1 & I \\
\hline Exchangeable Al (ind.65) & 00.2 & III \\
\hline Character vertic (ind. 11.12) & Absent & I \\
\hline Slope (ind.33) & $1 \%$ & I \\
\hline The unevenness of the terrain (ind.8) & 1 & I \\
\hline Impairment of land by surface erosion (ind.188) & 1 & I \\
\hline Erosion depth (ind.37) & 00 & I \\
\hline Landslides (ind.38) & Absent & I \\
\hline Depth of groundwater (ind.39) & 03.5 & I \\
\hline Volume of soil nongleyed (ind.137) & 95 & I \\
\hline The intensity of excess moisture (ind.181) & 1 & I \\
\hline Volume of soil non-pseudo-gleyed (ind.137) & 95 & I \\
\hline Seeping side on slope (ind.184) & 1 & I \\
\hline Inundability by overflow (ind.40) & 0 & I \\
\hline Drainage of groundwater (ind.107) & 3 & II \\
\hline The average temperature (ind.3C) & 9 & II \\
\hline The absolute minimum temperature (ind.98) & $25-35$ & III \\
\hline Thermal amplitude XII -II & $5-25$ & \\
\hline Precipitation corrected V -VII & & III \\
\hline Suitability classes for Cherry tree & & \\
\hline
\end{tabular}

requirements against limiting factors considered for calculating suitability note. The farmer has the opportunity to check through Excel table territory framing interested annexed in note suitability classes awarded for tree species.

The main drawback is the inaccuracy of the data which were available to draw up maps of favorability, after which several localities considered as traditional orchards and ponds received smaller notes of suitability. The new methodology does not take into consideration a number of limiting pedological factors as: the degree of excess moisture, salinity and alkalizing, active carbonates and danger of chlorosis phenomenon, factors that can restrict partial or complete, depending on the possibilities of improvement, of the establishment of new orchards.

\section{REFERENCES}

1. Anderson I, Richardson T (2006). Novel methods improve prediction of species distribution from occurred data, Ecography 29:129-151.

2. Florea N, Balaceanu V, Rauta C, Canarache A (1987). Methodology to elaborate soil studies, vol. I, II and III. Editorial agricultural propaganda, Bucharest.

3. Florea N, Munteanu I (2012). Romanian system of soil classification, Ph. Sitech, Craiova.

4. Gaoudriaan van Laar (1994). Effect of light and temeperature on potential orchards production, IV International Sympozium of computer modeling, Wageningen, P: 26-35.

5. Rusu M, Marghitas M, Mihailescu T, Oroian I, Dumitras A (2005). Agrochemical Treaty, Ph. Ceres, Cluj-Napoca.

6. ***, Archives from OSPA Cluj-Napoca.

7. ***, (1997). Romanian Geography, Ph. Academica, Bucharest.

8. ***, (2014). INCDPAPM-ICPA, Resource estimation methodology of pedoclimatic suitability of lands and orchards. 